\title{
Futile High-level Adipate Transport Activity Impairs Survival of Pseudomonas putida under Starvation Conditions
}

\author{
By CAROLINE S. HARWOOD ${ }^{1 *}$ AND L. NICHOLAS ORNSTON ${ }^{2}$ \\ ${ }^{1}$ Department of Microbiology, University of Iowa, Iowa City, Iowa 52242, USA \\ ${ }^{2}$ Department of Biology, Yale University, New Haven, Connecticut 06511, USA
}

(Received 1 March 1988; revised 26 April, 1988)

\begin{abstract}
Pseudomonas putida forms an inducible $\beta$-ketoadipate transport system that is expressed optimally under conditions of carbon and energy starvation. Adipate is a non-metabolizable analogue for the $\beta$-ketoadipate transport system and exposure to adipate of $\boldsymbol{P}$.putida strains that constitutively form high levels of the transport system resulted in an extensive loss in viability during starvation. Full viability was retained when the mutants were starved in the absence of adipate, and wild-type $P$. putida cells survived well either in the presence or absence of adipate. A possible cause of death during starvation in the presence of adipate is depletion of energy reserves by futile cycling of adipate via the active transport system. Sensitivity of the constitutive strains to killing by adipate indicates the necessity for tight control over the expression of transport systems during bacterial starvation to ensure survival.
\end{abstract}

\section{INTRODUCTION}

Non-sporulating bacteria can survive for substantial periods of time in the absence of external nutrients, and specific genes appear to be called into play during starvation (Amy \& Morita, $1983 a$; Groat \& Matin, 1986; Groat et al., 1986; Jaan et al., 1983; Kjelleberg et al., 1987; Spector et al., 1986, 1988). Some of the genes associated with starvation have been suggested to encode transport systems that might allow cells to scavenge low levels of nutrients (Amy \& Morita, 1983b; Davis \& Robb, 1985; Faquin \& Oliver, 1984; Mårdén et al., 1987; Morita, 1982). These interpretations provide a conceptual framework that may account for the presence of a seemingly anomalous $\beta$-ketoadipate transport system in fluorescent Pseudomonas species.

Discovery (Ornston \& Parke, 1976) of the inducible $\beta$-ketoadipate transport system in Pseudomonas putida was surprising because Stanier (1947) had demonstrated that a low rate of entry of $\beta$-ketoadipate into cells severely limited its respiration. Indeed, fully induced levels of the transport system do not support rapid respiration of $\beta$-ketoadipate by wild-type cells and transport remains the limiting step in respiration of $\beta$-ketoadipate by $P$. putida cells in which a regulatory mutation has increased expression of the transport system 20 -fold over fully induced wild type levels (Ondrako \& Ornston, 1980; Parke \& Ornston, 1976). These observations make it difficult to conclude that the transport system makes a major contribution to growth, but evolutionary conservation of the system in all biotypes of $P$. putida and $P$. fluorescens examined suggests that it confers some selective advantage (Ondrako \& Ornston, 1980). The system is both repressed (Parke \& Ornston, 1976) and inhibited (Ornston \& Parke, 1976) by growth substrates, so it appears likely that the selective benefit of the system is associated less with growth than with the scavenging of $\beta$-ketoadipate during starvation survival, the physiological circumstance in which the system achieves highest expression.

Optimal expression of the $\beta$-ketoadipate transport system in wild-type cells is not high when compared with levels in constitutive mutant strains (Parke \& Ornston, 1976; Ondrako \& Ornston, 1980), and this observation raises the possibility that overexpression of the system might be disadvantageous under some circumstances. A possible disadvantage is that adipate, 
which is a substrate for the transport system, does not serve as a growth substrate for representatives of $P$. putida (Stanier et al., 1966). Therefore, energy dependent (Ondrako \& Ornston, 1980) transport of the compound in the absence of its metabolism (Ornston \& Parke, 1976) might harm cells by depletion of energy reserves during starvation. In this paper we present evidence suggesting that this is the case.

\section{METHODS}

Bacterial strains. Strains of $P$. putida used in this investigation have been described previously (Parke \& Ornston, 1976). The wild-type strain PRS2000 is phenotypically indistinguishable from its parental strain PRS1 (ATCC 12633), the type strain for P. putida (Stanier et al., 1966) and the organism demonstrated by Stanier (1947) to be limited by permeability in its ability to respire $\beta$-ketoadipate. Strain PRS2015 carries a catB mutation that prevents its growth with benzoate (Wheelis \& Ornston, 1972). Strains PRS2243 and PRS2178, respectively derived from strains PRS2000 and PRS2015, express the $\beta$-ketoadipate transport system constitutively at levels 20-fold higher than fully-induced wild-type cells (Parke \& Ornston, 1976).

Media and growth conditions. All strains were cultivated at $30^{\circ} \mathrm{C}$ in defined basal medium (Ornston \& Stanier, 1966) supplemented with succinate $(10 \mathrm{mM}$, final concentration), glucose $(10 \mathrm{mM}$, final concentration) or $p$-hydroxybenzoate ( $5 \mathrm{mM}$, final concentration). Broth cultures were grown with constant aeration provided by a gyratory New Brunswick environmental shaker. Growth was monitored by the increase in optical density at $660 \mathrm{~nm}$.

Starvation experiments. Cells to be used in carbon and energy starvation experiments were grown in basal medium broth supplemented with $10 \mathrm{~mm}$-succinate and were harvested in the exponential phase of growth when they reached a concentration of approximately $5 \times 10^{8}$ cells ml-1. Cells were washed and resuspended in $100 \mathrm{ml}$ of basal medium to a final density of 1 to $2 \times 10^{7}$ cells ml ${ }^{-1}$. When two strains were co-starved, each was suspended at an initial density of about $1 \times 10^{7}$ cells ml ${ }^{-1}$. Starvation cultures were maintained with shaking in $500 \mathrm{ml}$ baffled Erlenmeyer flasks. Where appropriate, the disodium salt of adipate was added aseptically to starvation cultures at the onset of starvation. In some cases starvation conditions were established by growing cells in basal medium supplemented with a growth-limiting concentration of succinate $(0.1 \mathrm{~mm})$. Growth ceased and starvation was initiated upon exhaustion of the succinate from the medium (cell concentration 1 to $2 \times 10^{7} \mathrm{cells}^{-1}$ ). These two starvation protocols yielded cultures with indistinguishable survival characteristics.

Viability determinations. Viable cell numbers were determined by counting colonies after spreading dilutions of cultures on basal medium plates solidified with $1.5 \%(\mathrm{w} / \mathrm{v})$ purified Oxoid agar and containing the following carbon sources. To determine the concentration of viable cells surviving in co-culture, medium containing $0.5 \mathrm{mM}$ succinate and $5 \mathrm{~mm}$-benzoate was used to distinguish large colonies that could grow with benzoate from small colonies that could not utilize benzoate as a growth substrate. Starvation cultures containing only PRS2178 cells were spread on agar plates supplemented with $10 \mathrm{mM}$-succinate.

ATP determinations. The ATP content of cells was determined with the firefly luciferin-luciferase reaction (Holm-Hansen \& Booth, 1966). ATP extraction buffers, luciferin-luciferase reagents and the ATP assay procedure were obtained from Analytical Luminescence Laboratory. Cells from $1.5 \mathrm{ml}$ of a suspension of starving cells were harvested using a microcentrifuge and resuspended in $200 \mu \mathrm{HEPES} / \mathrm{NaOH}$ buffer $(\mathrm{pH} 7.75)$ and $200 \mu 1$ Extralight-ATP releasing agent to extract cellular ATP. Luciferase assays were done by following light emission with a Turner Designs ATP photometer.

Adipate transport assays. Adipate transport (Ondrako \& Ornston, 1980) was measured in cells that were starved in the absence of adipate and then harvested, washed, and re-suspended in $0.85 \% \mathrm{NaCl}$ to a protein concentration of $0.55 \mathrm{mg} \mathrm{ml}^{-1}$. Protein was determined as previously described (Harwood \& Gibson, 1986). Transport assays were initiated by making a 10 -fold dilution of the cell suspension into $0.2 \mathrm{M}$-sodium phosphate buffer $(\mathrm{pH} 6.0)$ containing $20 \mu \mathrm{M}-\left[1,6-{ }^{-14} \mathrm{C}\right] a d i p a t e$. Assay mixtures were maintained at 20 to $24{ }^{\circ} \mathrm{C}$. Samples $(0.1 \mathrm{ml})$ were removed at intervals ranging between $10 \mathrm{~s}$ and $10 \mathrm{~min}$ and filtered through $0.2 \mu \mathrm{m}$ pore diameter polycarbonate membranes (Nucleopore Co.). The filters were washed before and after sample addition with $2 \mathrm{ml}$ of the phosphate buffer. The washed filters were placed in $3 \mathrm{ml}$ of Liquiscint (National Diagnostics Inc.) and the radioactivity was determined in a Beckman scintillation counter.

Chemicals. $\left[1,6-{ }^{-14} \mathrm{C}\right]$ Adipic acid $\left(10 \mu \mathrm{Ci} \mu \mathrm{mol}^{-1} ; 370 \mathrm{kBq} \mu \mathrm{mol}^{-1}\right)$ was obtained from ICN Pharmaceuticals. All other chemicals were reagent grade.

\section{RESULTS}

\section{High levels of futile adipate transport cause death of starved cells}

The hyperconstitutive mutant strain PRS2178 forms the $\beta$-ketoadipate transport system at levels 20 -fold higher than those found in induced wild-type cells (Parke \& Ornston, 1976). When 


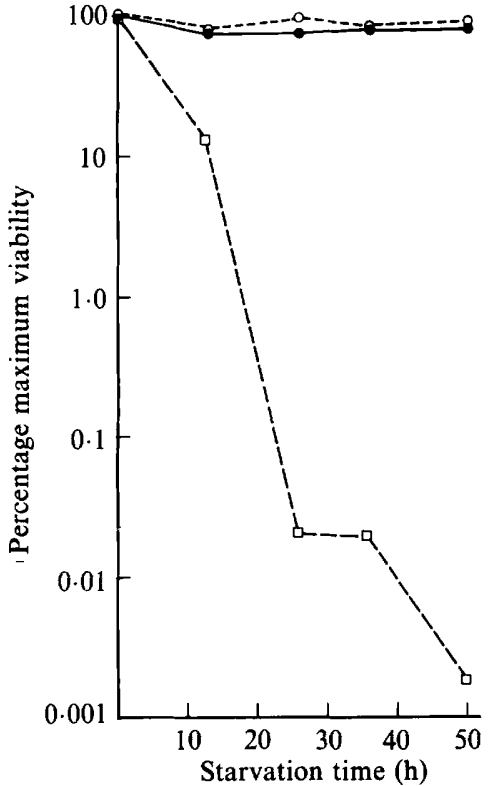

Fig. 1

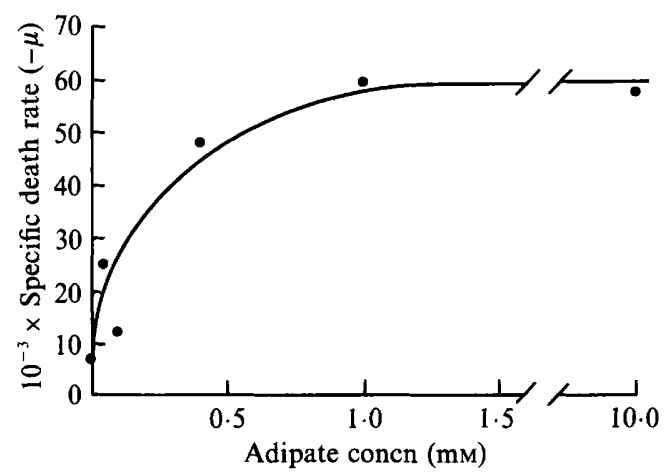

Fig. 2

Fig. 1. Viabilities of wild-type (PRS2000) and $\beta$-ketoadipate transport-constitutive (PRS2178) strains in the presence or absence of adipate. Wild-type and mutant strains were co-starved for carbon in basal medium or in basal medium supplemented with $10 \mathrm{~mm}$-adipate as described in the text. O, PRS2000 starved in the presence of adipate;, PRS2178 starved in the absence of adipate; $\square$, PRS2178 starved in the presence of adipate.

Fig. 2. Effect of adipate concentration on viabilities of starving $\beta$-ketoadipate transport-constitutive (PRS2178) cells. The first order kinetics of viability loss are plotted in linear form. The specific death rate, $-\mu=-\ln \left(B_{\mathrm{t}} / B_{0}\right) / t$, where $B_{0}=$ the number of viable cells present in the starvation culture at the onset of starvation and $B_{\mathrm{t}}=$ the number of viable cells present in the starvation culture at time $t$ (in hours). PRS2178 cells were starved as pure cultures.

mutant and wild-type cells were co-starved as a mixed culture in the presence of adipate, $99.99 \%$ of the high-level transport constitutive mutant cells lost viability in $50 \mathrm{~h}$ whereas the viability of wild-type cells was unaffected (Fig. 1). Viability also remained constant when the transportconstitutive mutant cells were starved in the absence of adipate (Fig. 1).

Addition of adipate to pure cultures of strain PRS2178 caused loss of viability, but at a lower rate and to a smaller extent than that observed with the constitutive mutant cells in mixed cultures. For example, viability of the constitutive strain in single culture was typically $10 \%$ of the initial value after $50 \mathrm{~h}$ whereas $0.01 \%$ of the initial value was observed when the constitutive cells were co-starved in mixed culture with the wild-type organisms. The reason for this dramatic difference is not clear. It is possible that the wild-type cells contributed to the death of the constitutive mutant cells by depriving viable cells in the population of cellular constituents that became available as a result of cell death followed by cell lysis. Some cellular constituents, by serving as energy sources, would be expected to prolong the viabilities of cells in the starvation culture.

Strain PRS2178 was derived from a P. putida strain (PRS2015) that is unable to grow on benzoate due to a mutation in muconate lactonizing enzyme (catB). It was used in this study because the $\beta$-ketoadipate transport system has been studied and characterized the most extensively in this strain (Ondrako \& Ornston, 1980; Ornston \& Parke, 1976). Strains that express the $\beta$-ketoadipate transport system constitutively have also been derived directly from the wild-type strain PRS2000. The starvation-survival characteristics of one of these strains 
(PRS2243) were determined in both the presence and absence of adipate and were found to be similar to those of PRS2178 (data not shown). The death of PRS2178 cells upon starvation in the presence of adipate is therefore unrelated to the $\operatorname{cat} B$ mutation.

The ability of PRS2178 cells to transport adipate increased slightly at the onset of starvation and did not change significantly thereafter. Cells assayed at the onset of starvation and after starvation periods of 19,43 , and $67 \mathrm{~h}$, transported adipate at rates of $3 \cdot 3,5 \cdot 6,6 \cdot 0$ and $6 \cdot 1 \mathrm{nmol}$ $\mathrm{min}^{-1}$ (mg protein $)^{-1}$, respectively. Thus the transport system is functional in cells that have entered a state of starvation.

Maintenance of cell viability was not related to the growth substrate utilized by cells prior to exposure to starvation. PRS2178 cells that were grown with either succinate or glucose and then starved as pure cultures in the presence and absence of adipate had similar survival patterns. PRS2000 cells survived well when they were starved in the presence of adipate, regardless of whether they had been previously grown on succinate, glucose or $p$-hydroxybenzoate, a compound which elicits low-level expression of the $\beta$-ketoadipate transport system (Ondrako \& Ornston, 1980).

\section{Kinetics of death}

Viability measurements of carbon starved cells showed that the logarithm of the number of viable cells was approximately a linear function of starvation time. A specific death rate, analogous to the first order constant for radioactive decay, was termed $-\mu$. Here, $\mu=$ $\ln \left(B_{\mathrm{t}} / B_{0}\right) / t$, where $B_{0}=$ the number of cells present in the starvation culture at the onset of starvation and $B_{\mathrm{t}}=$ the number of viable cells present in the starvation culture at time $t$, in hours. In seven separate experiments PRS2178 cells that were carbon starved as pure cultures in the absence of adipate had an average $-\mu$ of $1.0 \pm 0.7 \times 10^{4} \mathrm{~h}^{-1}$. When starved as pure cultures in the presence of $10 \mathrm{~mm}$-adipate, PRS2178 cells exhibited an average $-\mu$ of $6.8 \pm 2.1 \times 10^{4}$ $h^{-1}$. These values corresponded to $50 \%$ survival times of $64 \mathrm{~h}$ in the absence of adipate and $9.8 \mathrm{~h}$ in the presence of adipate.

The specific death rates for strain PRS2178 responded to variations in adipate concentration with Michaelis-Menten kinetics with a half-maximal effect occuring at a concentration of about $2 \times 10^{-4} \mathrm{M}$ (Fig. 2), the same as the $K_{\mathrm{m}}$ (app) for adipate with the $\beta$-ketoadipate transport system of this organism (Ondrako \& Ornston, 1980). The death rate was essentially the same at external adipate concentrations of 1 or $10 \mathrm{mM}$ (Fig. 2). At these concentrations the transport system is saturated with respect to substrate (Ondrako \& Ornston, 1980) and the steady state ratio of internal to external adipate is approximately constant. Therefore at external adipate concentrations of greater than $1 \mathrm{mM}$, the rate of death is independent of the amount of adipate accumulated within the cells.

Starving cultures of the constitutive strain PRS2178 could be 'rescued' from the lethal effects of adipate by filtration and re-suspension in adipate-free starvation buffer (Fig. 3). Thus adipate did not appear to trigger a complex irreversible physiological process leading to the death of cells.

Adipate at a concentration of $1 \mathrm{~mm}$ did not discernably affect the rate or yield of growth of the constitutive strain PRS2178 with succinate. At a concentration of $10 \mathrm{mM}$, adipate slightly delayed the onset of growth with succinate, but did not significantly influence the growth yield. Therefore the lethal effects of adipate do not appear to be exercised in the presence of an effective carbon and energy source.

\section{ATP levels in starving cells}

The simplest interpretation of the findings presented above is that the death of cells during exposure to adipate is due to depletion of energy due to futile active transport of the compound. Support for this view derives from the fact that a decline in ATP content preceded loss in viability (Fig. 4). After $20 \mathrm{~h}$ exposure of strain PRS2178 to $10 \mathrm{~mm}$-adipate, ATP levels had decreased by $90 \%$ and the viable count was reduced by less than $50 \%$ (Fig. 4). In the absence of adipate, the ATP content of a culture of strain PRS2178 increased $60 \%$ during $12 \mathrm{~h}$ starvation. 


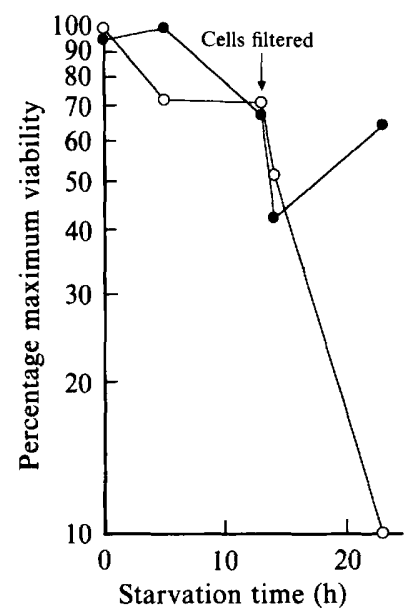

Fig. 3

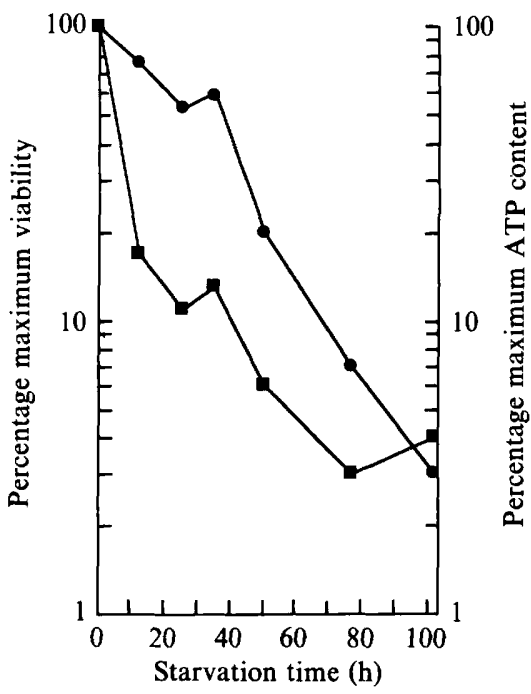

Fig. 4

Fig. 3. Effect of adipate removal on viabilities of starving cells. Pure cultures of strain PRS2178 were starved in the presence of $10 \mathrm{~mm}$-adipate. After $13 \mathrm{~h}$ (indicated by arrow), cells were collected by filtration onto sterile filters with a pore size of $0.22 \mu \mathrm{m}$, placed in flasks with basal medium, and resuspended by shaking for $20 \mathrm{~min}$. $\bigcirc$, Cells re-suspended in basal medium +10 mM-adipate; $\bigcirc$, cells resuspended in basal medium with no adipate.

Fig. 4. ATP levels in transport-constitutive mutant cells (PRS2178) starved as pure cultures in the presence of $10 \mathrm{~mm}$-adipate. Cells were suspended in basal medium at an initial density of $2 \times 10^{7} \mathrm{ml}^{-1}$. At the onset of starvation, cultures contained $2 \times 10^{-11}$ mols ATP ml ${ }^{-1}$. Percentage maximum viability; $\mathbf{D}$, percentage maximum ATP $\mathrm{ml}^{-1}$.

\section{DISCUSSION}

The massive losses of viability that we have observed appear to depend upon the futile activity of the constitutively expressed $\beta$-ketoadipate transport system during starvation. High-level expression of the transport system does not impede survival in the absence of adipate, and intracellular adipate per se does not appear to cause cell death. Appreciation of evidence supporting the latter conclusion is heightened by knowledge that the effectiveness of adipate as an inducer of the catC gene (Parke \& Ornston, 1976) affords a sensitive physiological measure of the intracellular concentration of adipate. Adipate elicits $30 \%$ of full expression of the catC gene when supplied to wild-type cells at an extracellular concentration of $10 \mathrm{mM}$, whereas similar levels of expression are observed in the transport constitutive cells at a concentration of $0.1 \mathrm{mM}$. The fact that $10 \mathrm{~mm}$-adipate was without effect on wild-type cells whereas $0.1 \mathrm{~mm}$-adipate markedly accelerated the death of constitutive organisms suggests that intracellular adipate itself was not the cause of cell death. The additional observation that transport constitutive cells died at a greatly accelerated rate when they were starved in mixed culture with wild-type cells is also consistent with the notion that adipate is not directly toxic but instead acts to potentiate the death of transport constitutive cells under starvation conditions. A possible basis for this particular observation is that the wild-type cells present in mixed starvation cultures deprived the transport-constitutive strain of potential energy sources or nutrients released from lysed cells.

The lethal effect of futile adipate transport was observed only in cells undergoing starvation. Although a determination of the precise cause of cell death will require more detailed studies, the simplest interpretation of this finding is that maintenance of the adipate concentration gradient deprives cells of metabolic energy required for survival. Consistent with this is the demonstration that a precipitous decline in ATP levels preceded cell death. 
Adipate had little effect on either the rate or the yield of growth of strains in which the $\beta$-ketoadipate transport system is expressed at high levels. It may be that the failure of adipate to inactivate growing cells is caused by the availability of energy sufficient to overcome any deficiencies caused by adipate transport. However, this interpretation may prove to be inadequate because it overlooks major differences between growing and starving cells. In the first few hours following the onset of starvation, many Gram-negative bacteria undergo a series of morphological and physiological changes that can be likened to a process of cell differentiation. The most obvious manifestations of these changes include a marked reduction in cell size and an eventual lowering of the rate of endogenous metabolism (Amy et al., 1983; Humphrey et al., 1983; Kjelleberg, 1984; Kjelleberg et al., 1983, 1987; Mårdén et al., 1985; Roszak \& Colwell, 1987). Various Gram-negative bacteria have also been shown to synthesize starvation-specific proteins (Amy \& Morita, 1983a; Groat \& Matin, 1986; Jaan et al., 1986; Spector et al., 1986), and a starvation-sensitive mutant of Escherichia coli has been isolated (Groat et al., 1986), indicating that at least some of the proteins are essential for survival in the absence of exogenous carbon and energy. We observed that transport-constitutive cells, when starved in the absence of adipate, underwent a morphological differentiation typical of nonsporeforming Gram-negative bacteria: the organisms became small and coccoid (data not shown). Wild-type cells starved in the presence or absence of adipate also differentiated to form very small cells. Transport-constitutive cells starved in the presence of adipate, on the other hand, retained the relatively large and rod-shaped appearance of growing cells and, prior to death, underwent a substantial loss of metabolic energy. These observations raise the possibility that the metabolic demands placed on cells during the period of major cellular re-organization preceding survival of starvation may render cells particularly sensitive to the deleterious consequences of decreased energy availability.

The specific conclusion that activity of the $\beta$-ketoadipate transport system contributed to loss of viability during starvation in the presence of adipate is strengthened by the fact that the $K_{\mathrm{m}}$ (app) of the transport system for adipate is indistinguishable from the concentration of adipate at which killing occurs at one-half the maximal rate. The conclusion may be further tested by selection of strains that resist death during starvation in the presence of adipate. In principle, the selected organisms might be expected to include mutant strains that do not express the transport system at high levels. In addition, the selected population might contain mutant strains carrying compensatory selective functions and thus might afford an avenue into exploration of the physiology of the survival state. The conclusion that the deleterious effects of the constitutive production of the $\beta$-ketoadipate transport system are not related to any properties inherent in the substrate transported other than that it is not metabolized by cells also leads to the prediction that similar effects would be observed with other inappropriately regulated transport systems. General analysis of the contribution of futile transport to death during starvation should be possible because the technique used to select for $\beta$-ketoadipate transport-constitutive strains appears to be applicable to other transport systems (Cohen-Bazire \& Jolit, 1953; Parke \& Ornston, 1976; Romano et al., 1980).

Expression of the $\beta$-ketoadipate transport system never exceeds low levels in wild-type $P$. putida, and it is tempting to speculate that death due to futile adipate transport during starvation contributes to maintenance of tight control over expression of the transport system. This line of reasoning demands that the potentially lethal agent adipate, a substrate that fails to support growth of members of $P$. putida (Stanier et al., 1966), is encountered by the bacteria in their habitat. Such may be the case because adipate serves as a growth substrate for representatives of the closely related species $P$. aeruginosa (Stanier et al., 1966).

This investigation was supported by Celgene Corp., and by the US Army Research Office.

\section{REFERENCES}

AMY, P. S. \& MoRitA, R. Y. (1983a). Starvationsurvival of sixteen freshly isolated open-ocean bacteria. Applied and Environmental Microbiology 45, 1109-1115.
AMY, P. S. \& MoRITA, R. Y. (1983b). Protein patterns of growing and starved cells of a marine Vibrio sp. Applied and Environmental Microbiology 45, 17481752. 
Amy, P. S., Pauling, C. \& Morita, R. Y. (1983). Starvation-survival processes of a marine Vibrio. Applied and Environmental Microbiology 45, 10411048.

COHEN-BAZIRE, G. \& Jolit, M. (1953). Isolement par sélection de mutants d'Escherichia coli synthétisant spontanement l'amylomaltase et la $\beta$-galactosidase. Annales de l'Institut Pasteur 84, 937-945.

DAvis, C. L. \& RoBB, F. T. (1985). Maintenance of different mannitol uptake systems during starvation in oxidative and fermentative marine bacteria. Applied and Environmental Microbiology 50, 743-748.

Faquin, W. C. \& Oliver, J. D. (1984). Arginine uptake by a psychrophilic marine Vibrio sp. during starvation-induced morphogenesis. Applied and Environmental Microbiology 130, 1331-1335.

Groat, R. G. \& Matin, A. (1986). Synthesis of unique polypeptides at the onset of starvation in Escherichia coli. Journal of Industrial Microbiology 1, 69-73.

Groat, R. G., Schultz, J. E., ZYChLINSKY, E., Bockman, A. \& Matin, A. (1986). Starvation proteins in Escherichia coli: kinetics of synthesis and role in starvation survival. Journal of Bacteriology 168, 486-493.

HARWOOD, C. S. \& GiBson, J. (1986). Uptake of benzoate by Rhodopseudomonas palustris grown anaerobically in light. Journal of Bacteriology 165, 504-509.

Holm-Hansen, O. \& Booth, C. R. (1966). The measurement of adenosine triphosphate in the ocean and its ecological significance. Limnology and Oceanography 14, 528-532.

Humphrey, B., KJelleberG, S. \& Marshall, K. C. (1983). Responses of marine bacteria under starvation conditions at a solid-water interface. Applied and Environmental Microbiology 45, 43-47.

JAAN, A. J., DAHLlÖF, B. \& KJELlEbERG, S. (1986). Changes in protein composition of three bacterial isolates from marine waters during short periods of energy and nutrient starvation. Applied and Environmental Microbiology 52, 1419-1421.

KJELLEBERG, S. (1984). Effects of interfaces on survival mechanisms of copiotrophic bacteria in low-nutrient habitats. In Current Perspectives in Microbial Ecology, pp. 151-159. Edited by M. J. Klug \& C. A Reddy. Washington, DC: American Society for Microbiology.

KJelleberg, S., Hermansson, M., Mårdén, P. \& JONES, G. W. (1987). The transient phase between growth and nongrowth of heterotrophic bacteria, with emphasis on the marine environment. Annual Review of Microbiology 41, 25-49.

KJELleberG, S., HumpHREY, B. A. \& MARShall, K. C. (1983). Initial phases of starvation and activity of bacteria at surfaces. Applied and Environmental Microbiology 46, 978-984.

Mårdén, P., Tunlid, A., Malmcrona-Friberg, K.,
Odham, G. \& KJelleberg, S. (1985). Physiological and morphological changes during short term starvation of marine bacterial isolates. Archives of Microbiology 142, 326-332.

MÅRdén, P., NySTRöM, T. \& KJElleberg, S. (1987). Uptake of leucine by a marine Gram-negative heterotrophic bacterium during exposure to starvation conditions. FEMS Microbiology Ecology 45, 233-241.

MoRITA, R. Y. (1982). Starvation-survival of heterotrophs in the marine environment. Advances in Microbial Ecology 6, 171-198.

OndRaKo, J. M. \& ORNSTON, L. N. (1980). Biological distribution and physiological role of the $\beta$-ketoadipate transport system. Journal of General Microbiology 120, 199-209.

ORnston, L. N. \& Parke, D. (1976). Properties of an inducible uptake system for $\beta$-ketoadipate in Pseudomonas putida. Journal of Bacteriology 125, 475-488.

ORnSton, L. N. \& StaniER, R. Y. (1966). The conversion of catechol and protocatechuate to $\beta$ ketoadipate by Pseudomonas putida. I. Biochemistry. Journal of Biological Chemistry 241, 3776-3786.

PARKe, D. \& ORNSTON, L. N. (1976). Constitutive synthesis of enzymes of the protocatechuate pathway and of the $\beta$-ketoadipate uptake system in mutant strains of Pseudomonas putida. Journal of Bacterio$\log y$ 126, 272-281.

Romano, A. H., VoYtek, A. \& BRUSkin, A. M. (1980). Energization of glucose transport by Pseudomonas fluorescens. Journal of Bacteriology 142, 755-762.

Roszak, D. B. \& Colwell, R. R. (1987). Survival strategies of bacteria in the natural environment. Microbiological Reviews 51, 365-379.

Spector, M. P., Aliabadi, A., Gonzalez, T. \& Foster, J. W. (1986). Global control in Salmonella typhimurium: two-dimensional electrophoretic analysis of starvation-, anaerobiosis-, and heat shock-inducible proteins. Journal of Bacteriology 168, 420-424.

Spector, M. P., Park, Y. K., Tirgari, S., Gonzalez, T. \& FosTER, J. W. (1988). Identification and characterization of starvation-regulated genetic loci in Salmonella typhimurium by using Mud-directed lac $Z$ operon fusions. Journal of Bacteriology 170, 345-351.

STANIER, R. Y. (1947). Simultaneous adaptation: a new technique for the study of metabolic pathways. Journal of Bacteriology 54, 339-348.

Stanier, R. Y., Palleroni, N. J. \& Doudoroff, M. (1966). The aerobic pseudomonads: a taxonomic study. Journal of General Microbiology 43, 159-271.

WheELIS, M. L. \& ORNSTON, L. N. (1972). Genetic control of enzyme induction in the $\beta$-ketoadipate pathway of Pseudomonas putida: deletion mapping of cat mutations. Journal of Bacteriology 109, 790795 . 